\title{
The Vestigial Axillary Strands of Trichomanes javanicum, B1.
}

\author{
BY \\ HELEN S. CHAMBERS, B.SC., F.L.S. \\ Assistant Lecturer in Botany, Royal Holloway College.
}

With Plate LXXX and five Figures in the Text.

INTRODUCTION.

T some specimens of Trichomanes javanicum collected by Dr. M. Benson 1 in Fiji, there were observed numerous examples of the curious vestigial axillary strand recorded in an allied species by Boodle. ${ }^{1}$ Boodle mentions the axillary strand, together with the fact that it fuses with the leaf-trace during its passage through the cortex; but he does not give any details of its structure nor of its ultimate fate beyond the following general statement : - Axillary branches occur very generally in the Hymenophyllaceae ; at many nodes, however, the rudiment of the axillary branch may remain undeveloped.'

The axillary shoot first discovered by Stenzel, and later recorded in other species of Zygopteris, is discussed by Scott in his Studies, where he mentions (p. $\left.3^{12}\right)$ that 'the axillary strand passed out into a cylindrical appendage placed exactly in the axil between stem and leaf'. The presence of a comparable structure has been suggested by Gwynne-Vaughan ${ }^{2}$ in Helminthostachys zeylanica, and by Bruchmann ${ }^{3}$ in Botrychium lunaria.

As the phenomenon seemed worthy of further investigation, especially with reference to the origin and ultimate fate of the strand, I determined to make a detailed examination of the new material. For this purpose microtome sections have been made through the apex of one plant, and through the bases of petioles. From some of the series longitudinal diagrams have been constructed.

\section{Habit of Trichomanes Javanicum, Bl.}

Trichomanes javanicum possesses an upright stem, about $2.6 \mathrm{~mm}$. in diameter, which bears strong bipinnate fronds and many interlacing roots.

1 Boodle : Anatomy of the Hymenophyllaceae. Annals of Botany, vol. xiv, 1900. Whether this strand develops or not is left an open question by Boodle, loc. cit., p. 470.

2 Gwynne-Vaughan : Annals of Botany, vol. xvi, p. I7o.

8 Bruchmann: Flora, I906, p. 226.

[Annals of Botany, Vol. XXV. No. C. October, 1911.] 
No cases of normal branching have been observed in $T$. javanicum. Textfig. I, A, shows a curious case in which two stems, bearing about a dozen petioles, appear to dichotomize owing to the fact that they have grown in close proximity, and have become connected by the interweaving of their roots.

This erect unbranched habit seemed at first to give the clue to the

A

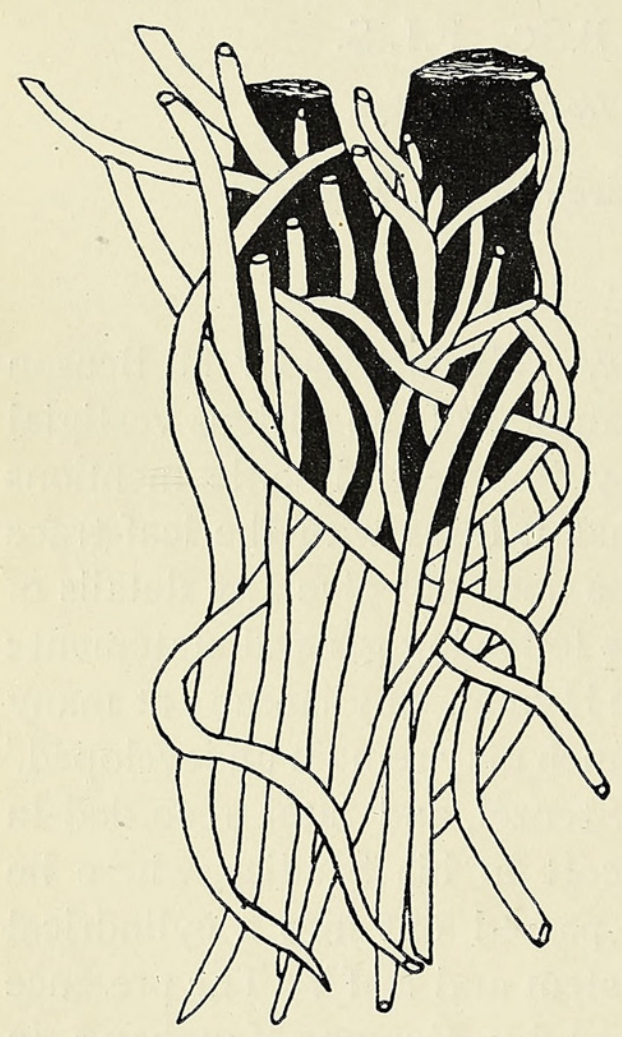

TEXT-FIG. I. A. Habit of Trichomanes javanicum. B. Petiole, showing tongue of tissue at the base.
$B$ branch. The presence of axillary strands is described by Boodle ${ }^{1}$ in $T$. Prieurii, which has an erect stem. But Gwynne-Vaughan 2 has described the occurrence, in a dorsiventral rhizome of Helminthostachys zeylanica, of canals leading from the axil of each leaf to the stele of the rhizome. Here each is met by a conical projection of parenchyma surrounded by endodermis. These, he suggests, represent vestigial axillary buds. Bruchmann ${ }^{3}$ found similar bodies on young plants of $B o$ trychium lunaria, which develop into lateral branches. He thus confirmed Gwynne-Vaughan's suggestion. The phenomenon is not, then, confined to forms with erect habit. Bower ${ }^{4}$ suggests that there are two ways in which underground-growing organisms can secure perennation; the first is by repeated branching and the appearance of some of the branches above ground for a time; the second method is by suppression of branching in the stock and enlargement of the few leaves. The suppression of branching in the forms under consideration is probably connected with growth underground, and is not correlated specially with either erect or dorsiventral habit.

\section{Stelar Anatomy of T. Javanicum.}

The stem possesses a central stele composed of a mass of xylem interspersed with parenchyma. The tracheides are nearly uniform in size, so that it is impossible to distinguish the protoxylem. The xylem is surrounded by a continuous ring of phloem, outside which is the pericycle and

1 loc. cit., p. 470.

2 loc. cit.

${ }^{3}$ loc. cit.

4 Origin of Land Flora, p. $43 \mathrm{r}$. 
endodermis. This species then resembles the T. spicatum type described by Boodle. ${ }^{1}$ Text-fig. 2 is a diagram of a transverse section of the stem. The central stele, $\mathrm{x}$, is giving off a meristele, $\alpha$, which will later divide to form a branch and a leaf-trace; $b$ is such a meristele which has travelled some distance in the cortex. A leaf-trace, $c$, has come off from the axillary branch, $x$, and lies on the same radius with it. The root $d$ is just going off from $\mathrm{x}$, the stem stele.

In structure the meristele closely resembles that of the stem as it is given off. It consists of a solid mass of xylem and parenchyma surrounded

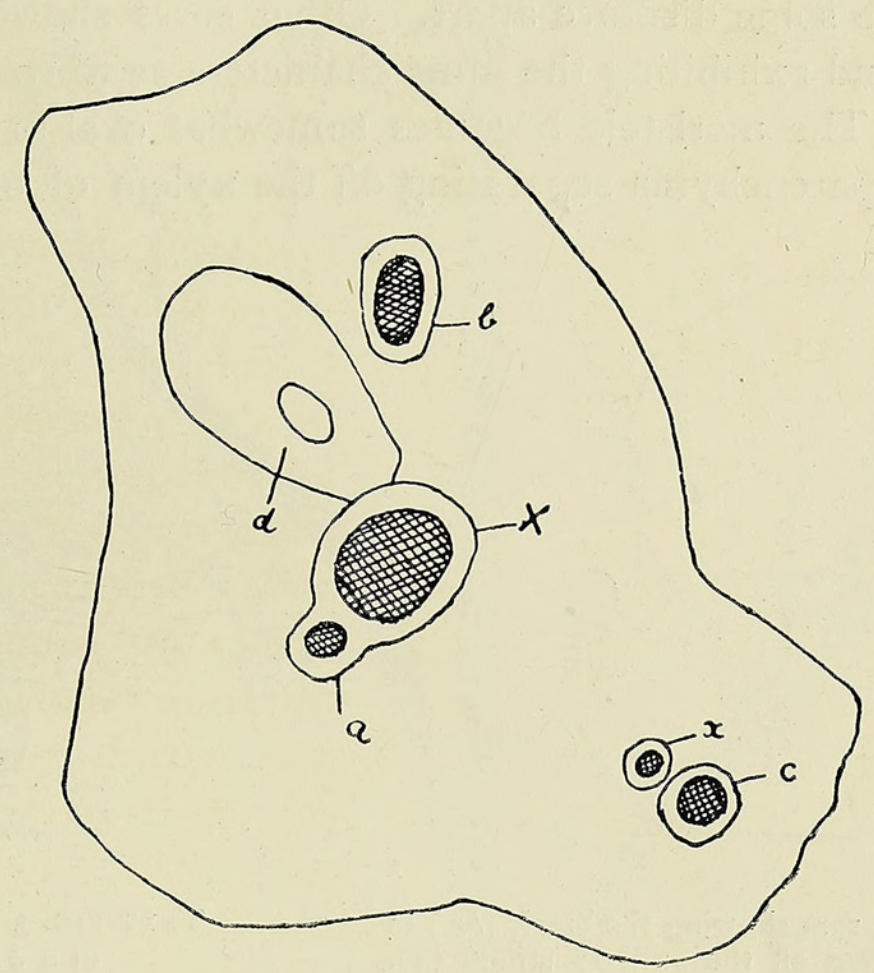

TEXT-Fig. 2.

by phloem, pericycle, and endodermis. It differs from the stem in having central protoxylem elements (P1. LXXX, Fig. I). This character is kept by the meristele as it passes through the cortex until it divides into branch and leaf-trace. This division takes place in some cases just before the meristele curves into the petiole, and in other cases the division is delayed until it has reached the petiole base or travelled a short distance up the petiole. The resulting strands lie on the same radius; the inner smaller strand is that of the axillary branch and the outer strand is the leaf-trace. In $T$. radicans, where the axillary branch develops normally, the inner strand is larger than the leaf-trace. Its diminution in size in $T$. javanicum is due to the fact that it eventually perishes. 


\section{MoRPhOlOGY OF THE AXILlaRy BRanch.}

It was found to be difficult to follow the axillary strand into the petiole in sections of the whole stem, so petiole bases were separated from the stem and examined. Examination with a lens showed, at the base of the petiole on the adaxial surface, a small tapering mass of tissue covered with brown hairs (Text-fig. I, B). This tissue came off as a whole in hand sections, so the petiole bases were embedded and cut with the microtome.

In several cases it was found that the division into axillary branch and leaf-trace had already taken place, in the cortex of the stem probably, so that the two were some distance apart. Other cases showed the meristele still undivided, and exhibiting the same characters as when it first came off from the stem. The meristele becomes somewhat oval in shape and soon shows a band of parenchyma separating off the xylem of one rounded end

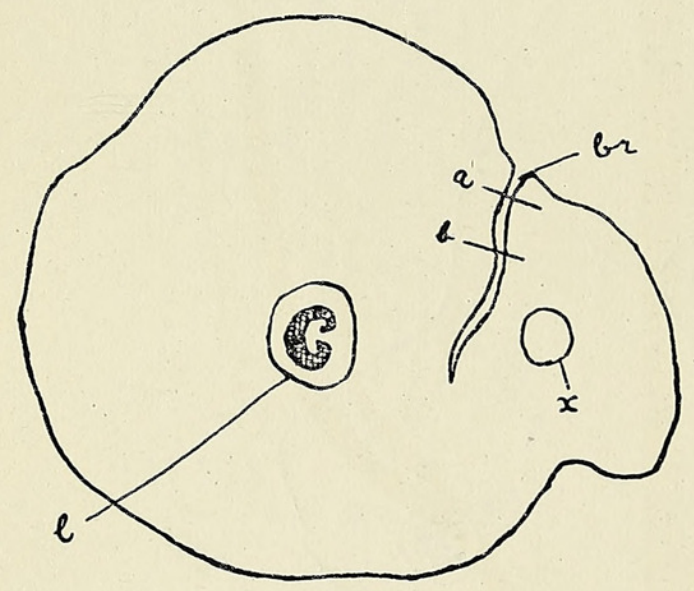

TeXT-FIG. 3 A. Diagram showing the break $(b r$.$) in$ the cortex separating off the axillary strand $(x)$. l, leaf-trace.

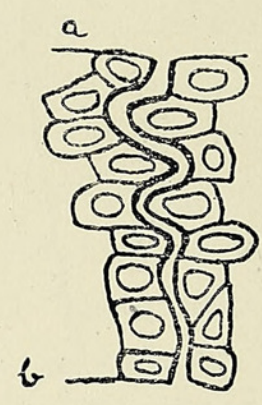

TEXT-FIG. 3 B. Enlargement of $a-b$ from 3 A.

to form the axillary strand (Pl. LXXX, Fig. 2). This separation goes on gradually until the axillary strand consists of a mass of xylem with parenchyma surrounded by phloem, pericycle, and endodermis. In every respect this strand resembles in structure the stem stele.

The leaf-trace has its xylem arranged round two groups of parenchyma with the thinner portion of the xylem on the flattened adaxial surface. Two groups of protoxylem can be distinguished in the parenchyma (Pl. LXXX, Fig. 3). Gradually the parenchyma aggregates into one group, and the thin band of xylem is interrupted by parenchyma cells, so that the metaxylem takes the arched form characteristic of the leaf-trace in Trichomanes. The protoxylem is in two groups, one at each incurved arm of the metaxylem.

The axillary branch strand passes very gradually through the cortex and diminishes in size. Pl. LXXX, Fig. 4, gives its structure when it is $0.075 \mathrm{~mm}$. away from the leaf-trace. As it moves further away the amount 
of xylem diminishes; for instance, at a distance of $0.16 \mathrm{~mm}$. from the leaftrace the branch stele possesses six lignified elements (Pl. LXXX, Fig. 5). This number is further reduced to two, and then to one lignified element at a distance of $0.23 \mathrm{~mm}$. from the leaf-trace (P1. LXXX, Fig. 6). The phloem also loses its differentiation until the strand is composed of a small mass of deeply-staining parenchyma (Pl. LXXX, Fig. 7). At this stage there is a distinct bulge in the cortex in which the strand is situated, and in some cases a break begins to appear between this portion and the rest of the cortex. Text-fig. 3 A gives a diagram showing the axillary branch, $x$, situated in a portion of the cortex which is separating from the rest by a break, $b r$,

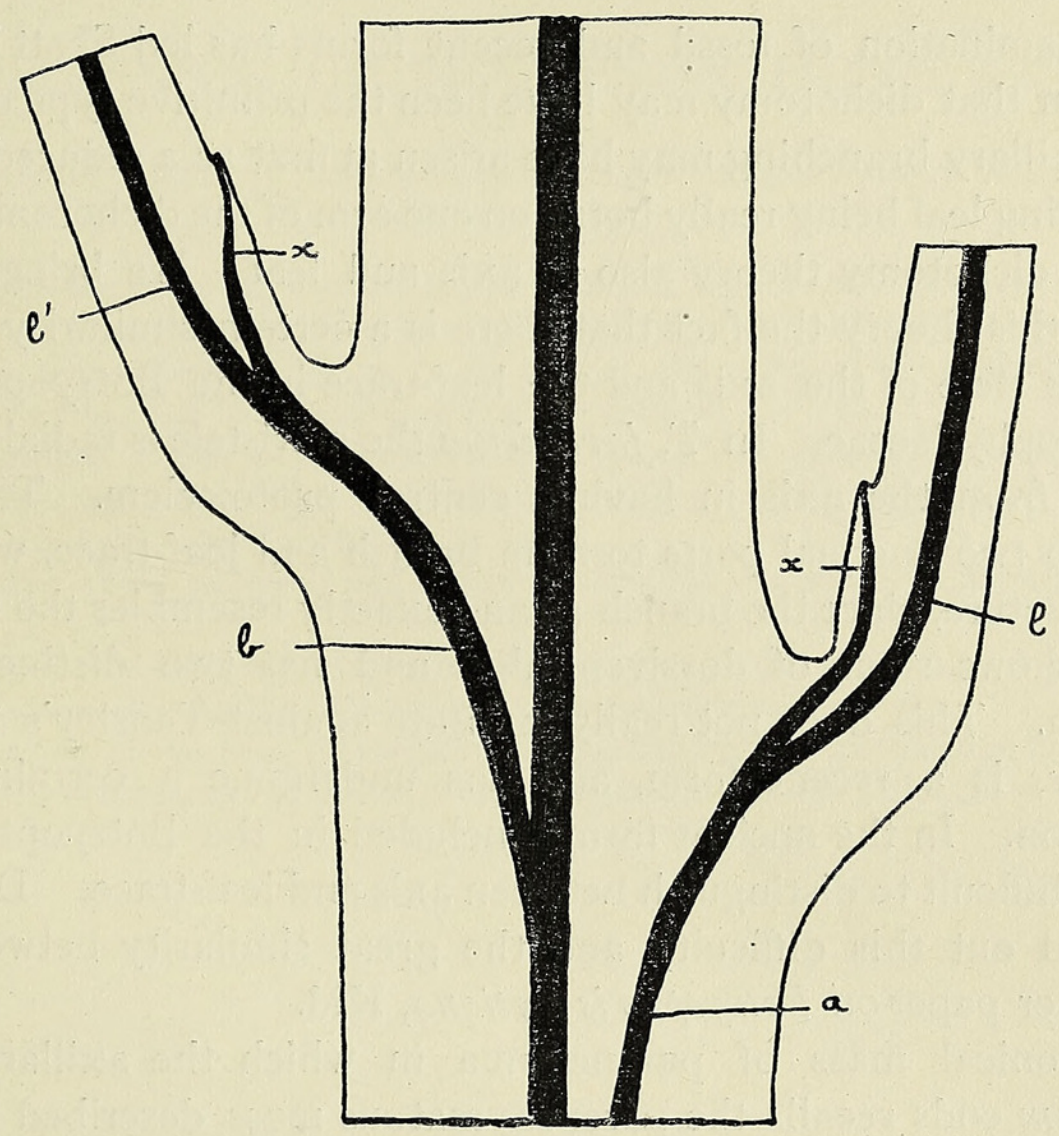

TEXT-FIG. 4 .

in the cortex cells. This break is apparently brought about by the dissolution of the middle lamella of these cells as shown in Text-fig. 3 B. Thus this tissue is gradually separated from the cortex of the petiole, and it disorganizes along with the remains of the branch stele. In other cases the break is not so distinct; the portion of the cortex containing the axillary strand projects beyond the rest. It gradually diminishes in size, and the tissue becomes disorganized. There is no doubt that this is the tapering mass of tissue visible on the adaxial surface of the petiole base.

From the serial sections of the stem and petiole bases it has been possible to reconstruct a longitudinal diagram of the course taken by the 
meristele. Text-fig. 4 shows that the meristele, $a$, passes slowly through the cortex until, just before it curves into the petiole, it divides to form the axillary branch, $x$, and the leaf-trace, $l$, which passes out into the petiole with $x$ towards the adaxial and $l$ towards the abaxial surface. The other meristele, $b$, figured in the diagram, reaches the petiole and there divides into branch strand, $x^{\prime}$, and leaf-trace, $l^{\prime}$. Each axillary branch strand gradually curves away from the leaf-trace and ends in a small protuberance of tissue on the adaxial surface.

\section{CONCLUSION}

An examination of fossil and recent forms has led Scott ${ }^{1}$ to mention a suggestion that dichotomy may have been the primitive type of branching, and that axillary branching may have arisen at first as a reduced dichotomy, the subtending leaf being really borne on one arm of the dichotomy. Tansley ${ }^{2}$ applies the dichotomy theory also to axis and leaf. He brings forward in support of this theory the fact that there is a certain similarity in structure between the stele of the axis and the leaf-trace in the Botryopterideae and the Hymenophyllaceae. In $T$. javanicum the meristele is radial in structure, but differs from the axis in having central protoxylem. The meristele divides into two unequal parts to form branch and leaf-trace, which are not alike in structure, since the branch strand exactly resembles the axis and the leaf-trace shows signs of dorsiventrality and has two distinct groups of protoxylem. This does not really militate against Tansley's theory, since Trichomanes is a recent form, and has undergone a certain amount of specialization. In the ancient forms included in the Botryopterideae it is often very difficult to distinguish between axis and leaf-trace. Dr. M. Benson has pointed out this difficulty and the great similarity between axis and petiole in her paper on Botryopteris antiqua, Kid.

The conical mass of parenchyma in which the axillary strand of $T$. javanicum ends recalls the parenchymatous mass, described by GwynneVaughan ${ }^{3}$ in Helminthostachys zeylanica as projecting from the stele of the axis to meet the base of each axillary canal. This tends to confirm his suggestion that these bodies 'represent the last indications of vestigial axillary buds'.4 Bower ${ }^{5}$ has recently pointed out in his paper on Ophioglossum palmatum that the trend of modern work is to relate the Ophioglossales to the Botryopterideae on account of the similarity in sporangial dehiscence, stipular structure, and heterophylly. To this list may now be added the

1 Studies in Fossil Botany, p. 3 I 8.

2 The Evolution of the Filicinean Vascular System. New Phyt. Reprint, I908, Lecture I.

3 loc. cit.

- Renault, in his publications in $\mathbf{I} 878$, regarded the Botryopterideae as related directly to the Hymenophyllaceae and Ophioglossaceae. See Studies in Fossil Botany, p. 640.

5 Annals of Botany, April, 1911. 
presence in both groups of vestigial axillary branches. The Botryopterideae and Hymenophyllaceae show great similarity in anatomy, and also possess vestigial axillary branches found in an increasing number of forms. It is obvious then that the Ophioglossales, Botryopterideae, and the Hymenophyllaceae are in one circle of affinity.

I wish to thank Dr. M. Benson for the material she has placed at my disposal, and for her helpful criticisms during the investigation recorded in this paper.

\section{DESCRIPTION OF FIGURES IN PLATE LXXX.}

\section{Illustrating Miss H. S. Chambers's paper on the Vestigial Axillary Strands of Trichomanes javanicum.}

Fig. 1. Transverse section of a meristele given off from the rhizome. The xylem shows central protoxylem $(p x)$ and is surrounded by phloem $(p h)$, pericycle $(p r)$, and endodermis。 $\times 180$.

Fig. 2. Transverse section of the meristele, showing the xylem of the axillary branch $(a)$ just separated from the leaf-trace $(l)$ by a layer of parenchyma $(p) . \quad \times \quad \mathbf{2} 5$.

Fig. 3. Transverse section of the leaf-trace after the axillary strand has separated, showing the first signs of the change from radial to dorsiventral structure. The two groups of protoxylem $(p x)$ are near the flattened side of the leaf-trace. $\times 125$. $\times 180$.

Fig. 4. Section of the axillary strand separated from the leaf-trace by a distance of $0.075 \mathrm{~mm}$.

Fig. 5. The same at a distance of $0.16 \mathrm{~mm}$. from the leaf-trace. $\times 180$.

Fig. 6. The same at a distance of $0.23 \mathrm{~mm}$. from the leaf-trace. $\times 180$.

Fig. 7. Section of the mass of parenchyma representing the last stage in the axillary strand when it is situated in the tongue of tissue on the adaxial surface of the petiole. $\quad \times 180$. 

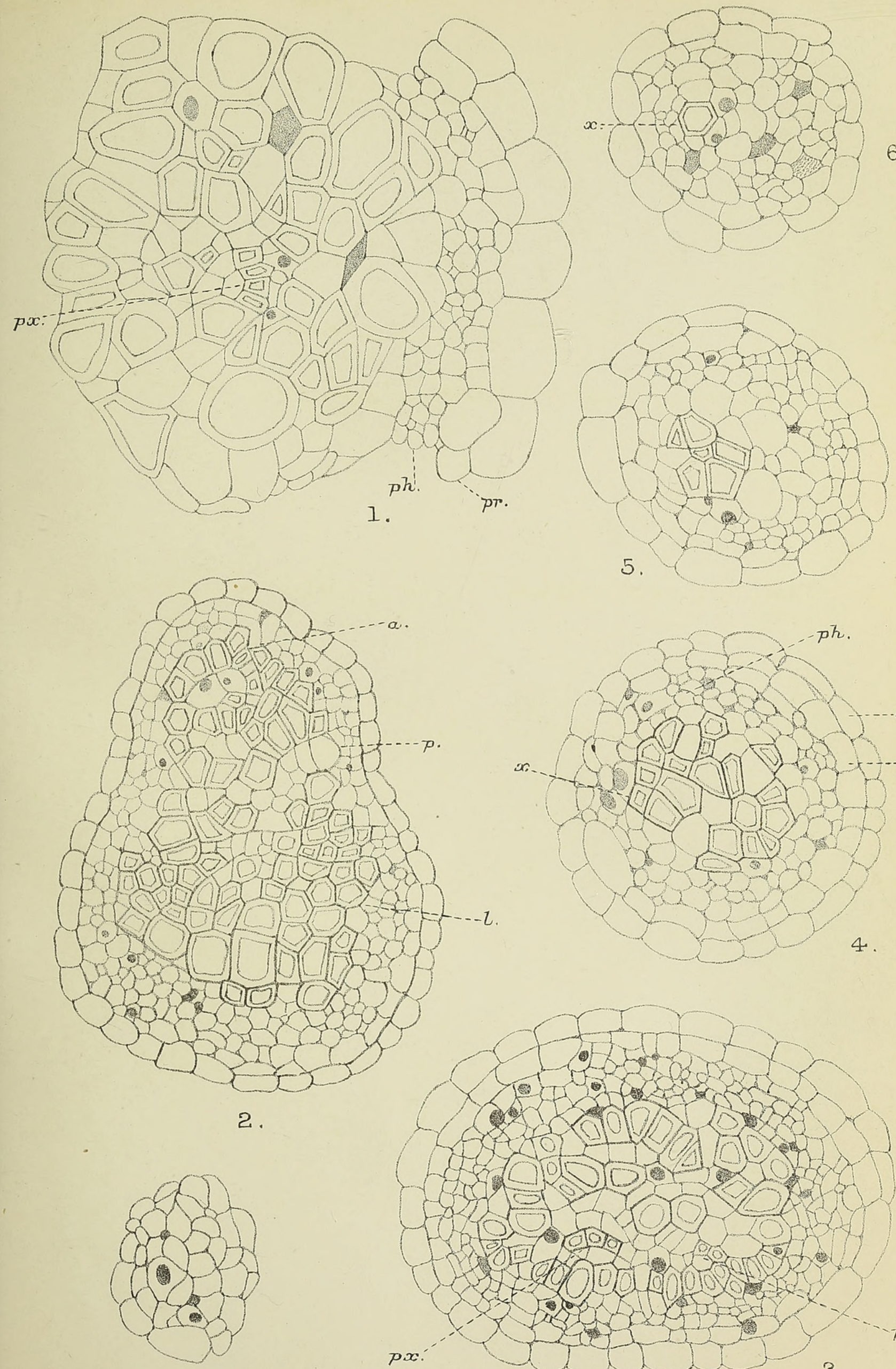

7.
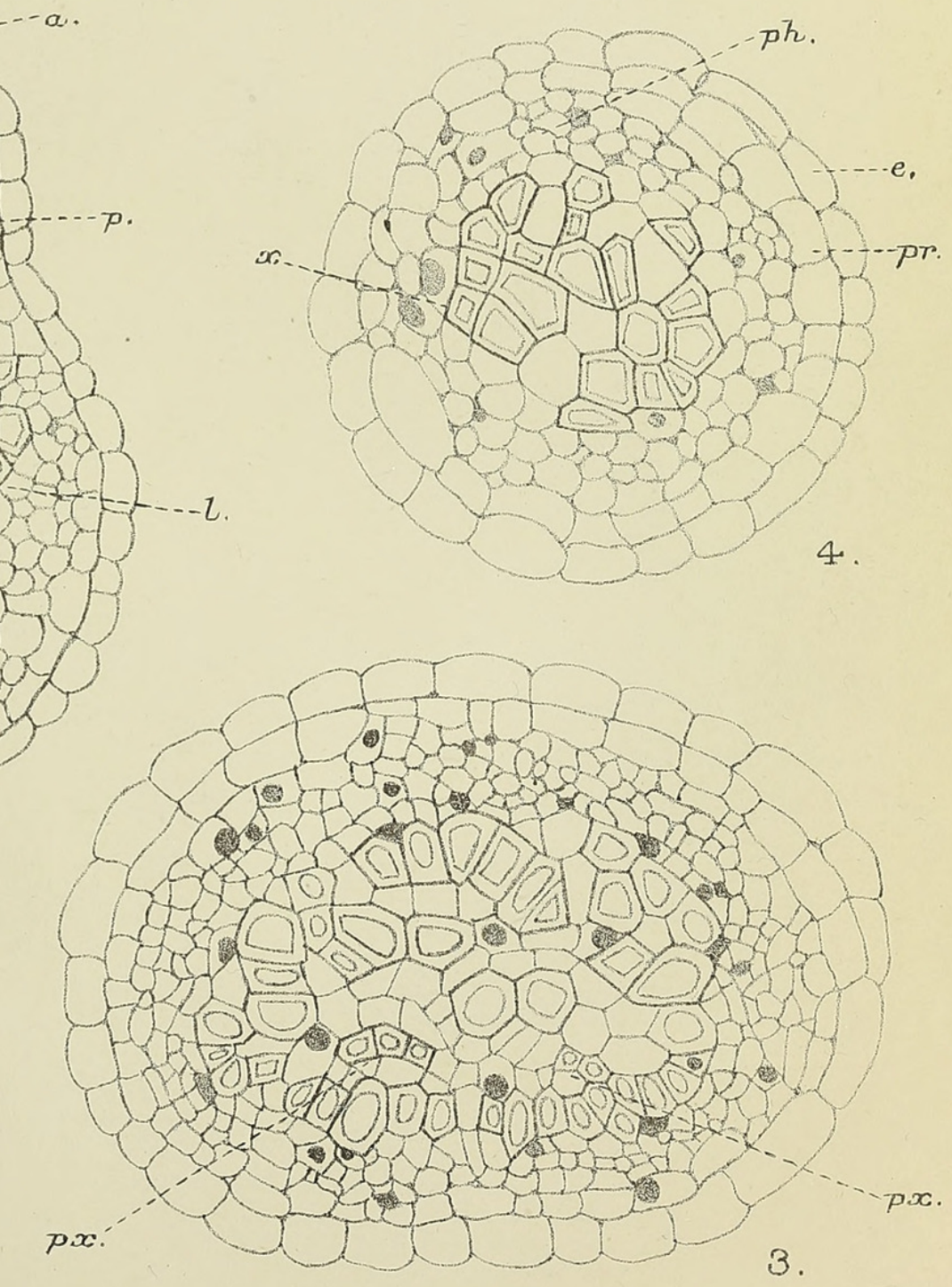
3.

CHAMBERS - TRICHOMANES. 


\section{$2 \mathrm{BHL}$ Biodiversity Heritage Library}

Chambers, Helen S. 1911. "The vestigial axillary strands of Trichomanes javanicum, Bl." Annals of botany 25, 1037-1043.

https://doi.org/10.1093/oxfordjournals.aob.a089360.

View This Item Online: https://www.biodiversitylibrary.org/item/239487

DOI: https://doi.org/10.1093/oxfordjournals.aob.a089360

Permalink: https://www.biodiversitylibrary.org/partpdf/319875

\section{Holding Institution}

Smithsonian Libraries

\section{Sponsored by}

Biodiversity Heritage Library

\section{Copyright \& Reuse}

Copyright Status: Not in copyright. The BHL knows of no copyright restrictions on this item.

This document was created from content at the Biodiversity Heritage Library, the world's largest open access digital library for biodiversity literature and archives. Visit BHL at https://www.biodiversitylibrary.org. 